\title{
KERJASAMA INDONESIA - NORWEGIA MELALUI SKEMA REDUCING EMISSIONS FROM DEFORESTATION AND FOREST DEGRADATION (REDD+) DALAM UPAYA PENYELAMATAN HUTAN INDONESIA
}

\author{
Nadhea Lady \\ Program Studi Ilmu Hubungan Internasional Fakultas Ilmu Sosial dan Ilmu Politik Universitas Komputer Indonesia \\ Jalan Dipati Ukur No. 112 Bandung 40132 Indonesia \\ E-mail:nadhealady@yahoo.co.id
}

\begin{abstract}
This study used qualitative research type. The research method used is descriptive analysis techniques. Most of the data collected through the literature, searching websites, and interviews. Those data were analyzed by theory approach based on International Relations, Foreign Policy, International Cooperation, International Agreement, and Environmental.

The results of this study indicate that the cooperation between Indonesia - Norway through the REDD scheme is poured into the form of a Letter of Intent (LoI) agreed on three phases in order to save Indonesia's forest despite undergoing a new stage in the first phase, this cooperation has resulted although not significantly.
\end{abstract}

Keywords: Environmental, REDD, Indonesia, Norway, Indonesian Forest

\begin{abstract}
ABSTRAK
Penelitian ini bertujuan untuk mengetahui bagaimana kerjasama yang dilakukan antara Indonesia - Norwegia melalui skema Reducing Emissions from Deforestation and Forest Degradation (REDD+) dalam upaya penyelamatan hutan Indonesia. Yang menjadi objek dari penelitian ini adalah hutan Indonesia, skema REDD dan kerjasama Indonesia - Norwegia. Peneliti mencoba memahami dan menganalisis kerusakan hutan yang terjadi di Indonesia dan peran REDD dalam usaha meminimalisir kerusakan tersebut.

Tipe penelitian ini adalah kualitatif. Metode penelitian yang digunakan adalah teknik analisa deskriptif. Sebagian besar data dikumpulkan melalui studi pustaka, penelusuran website, dan wawancara. Data-data yang diperoleh kemudian dianalisis dengan pendekatan teori yang berhubungan dengan Hubungan Internasional, Politik Luar Negeri, Kerjasama Internasional, Perjanjian Internasional dan Lingkungan Hidup.

Hasil dari penelitian ini menunjukkan bahwa kerjasama Indonesia - Norwegia melalui skema REDD yang dituang kedalam bentuk Letter of Intent (LoI) menyepakati tiga fase dalam upaya penyelamatan hutan Indonesia yang meskipun baru menjalani tahapan dalam fase pertama, kerjasama ini telah membuahkan hasil meskipun belum signifikan.
\end{abstract}

Kata Kunci : Lingkungan Hidup, REDD, Indonesia, Norwegia, Hutan Indonesia 


\section{PENDAHULUAN}

\subsection{Latar Belakang}

Isu lingkungan hidup telah menjadi pembicaraan penting dalam beberapa dekade terakhir. Permasalahan mengenai lingkungan hidup menarik perhatian berbagai pihak baik di tingkat lokal, nasional bahkan global. Isu ini pertama kali diangkat sebagai agenda dalam hubungan internasional pada tahun 1970-an, dan kini kepedulian terhadap lingkungan hidup menjadi isu global karena proses yang menyebabkan terjadinya eksploitasi yang berlebihan dan degradasi lingkungan berhubungan dengan prosesproses politik dan sosial-ekonomi yang lebih luas, dimana proses-proses tersebut merupakan bagian dari ekonomi politik global (Baylis dan Smith, 2011: 315). Isu ini menjadi permasalahan global dikarenakan jika terdapat kerusakan lingkungan di suatu wilayah, bukan hanya wilayah yang bersangkutan yang merasakan dampak negatif namun juga dapat dirasakan secara global.

Reducing Emission from Deforestation and Forest Degradation (REDD) disepakati pada COP tentang perubahan iklim di Montreal, Kanada di tahun 2005. REDD merupakan sebuah mekanisme global yang memberikan insentif kepada negara berkembang pemilik hutan seperti Indonesia untuk melindungi hutannya. Skema ini mulai hangat diperbincangkan dalam putaran perundingan perubahan iklim.

REDD dirancang oleh Papua Nugini dan Kosta Rika, dua negara pemilik hutan tropis yang merasa tidak mendapat keuntungan dari skema di bawah rezim Protokol Kyoto. Dua skema Protokol Kyoto, Emission Trading (ET) dan Joint Implementation (JI) hanya berlaku untuk dan di antara negara maju atau negara Annex I. Skema lain dari Protokol Kyoto, Clean Development Mechanism (CDM), memang turut melibatkan negara berkembang tetapi dibatasi tidak lebih dari $1 \%$ total emisi tahunan negara maju yang menginvestasikan proyek CDM-nya di negara berkembang. Jumlah yang sangat kecil ini tidak lepas dari prinsip pengurangan emisi domestik sebagai tujuan utama Protokol Kyoto. Artinya, mekanisme ET, JI, maupun CDM hanya pelengkap (additional) atas tujuan utama Protokol Kyoto yakni mendesak negara Annex I agar mengurangi emisi domestiknya (Murdiyarso, 2007: 48-59).

REDD berkembang dengan menambahkan tanda "plus" di belakangnya dengan menambahkan areal peningkatan cadangan karbon hutan ke dalam cakupan awal strategi REDD berupa peranan konservasi dan pengelolaan hutan secara lestari, pemulihan hutan dan penghutanan kembali, serta peningkatan cadangan karbon hutan (http://reddindonesia.org/index.php?option=com_content \&view $=$ article $\&$ id $=180 \&$ Itemid $=6$ diakses pada tanggal 13 04-2012). Sebagai tuan rumah dalam pertemuan COP ke-13, Indonesia berupaya memperjuangkan REDD+ sehingga bisa diterima negara-negara lain terutama oleh negara Annex I. Indonesia memang sangat berkepentingan terhadap skema REDD+, karena Indonesia merupakan negara dengan luas hutan tropika terbesar ketiga didunia, dimana Indonesia memiliki kawasan hutan seluas 133.433.366,98 Ha (hektare). Sekitar 47.236.000 $\mathrm{Ha}$ diklasifikasikan sebagai hutan primer, dan hutan karbon, dan sekitar 3.549.000 $\mathrm{Ha}$ sebagai hutan tanaman (http://rainforests.mongabay. com/deforestation/2000/Indonesia.htm diakses pada tanggal 13-04-2012).

REDD+ menjadi faktor penting dalam berbagai negoisasi internasional. Modelnya menuruti prinsip "common but differentiated responsibility" (kewajiban sama dengan tanggung jawab berbeda), dimana semua negara bertanggung jawab atas permasalahan lingkungan hidup ini namun bentuk pertanggungjawaban nya berbeda-beda sesuai dengan kapasitas masing-masing negara. Sebagai contoh, negara maju yang menghasilkan emisi dalam proses industrialisasi dan untuk menopang gaya hidup, menyediakan dana dan teknologi untuk negara berkembang sebagai bentuk komitmen dampak emisi karbon mereka. Sementara negara berkembang akan diberikan insentif untuk menjaga dan melestarikan hutannya.

Norwegia merupakan negara industri yang juga salah satu negara terkaya di dunia. Kekayaan materi disebabkan karena kekayaan sumber daya alam dan sebagian lain dikarenakan keikutsertaan Norwegia dalam industri Eropa Barat. Sejak tahun 1970, industri minyak lepas pantai telah memainkan peranan dominan dalam perekonomian Norwegia. Dengan laju industri yang pesat, Norwegia memiliki kebijakan lingkungan hidup untuk memastikan industrinya tidak bertentangan dengan lingkungan. Dalam hal ini, upaya untuk menerapkan penangkapan dan penyimpanan gas karbon (Capture and Storage of $\mathrm{CO}_{2}$ atau CCS) menjadi langkah yang penting.

Keberhasilan Norwegia dalam mencapai target lingkungan nasional bergantung pada kerjasama lingkungan internasional. Kerjasama lingkungan 
internasional penting dalam membangun kemampuan untuk merencanakan solusi yang baik dalam menghadapi tantangan lingkungan global yang di hadapi negara-negara di dunia dalam bentuk perubahan iklim, hilangnya keragaman biologi dan penyebaran zat kimia berbahaya ke lingkungan. Norwegia berperan penting dalam upaya menerapkan kerjasama internasional yang mengikat secara hukum dalam hal permasalahan lingkungan (Sigit Winarto, 2007).

Kebijakan manajemen lingkungan dan sumber daya merupakan komponen penting dari kebijakan kerjasama luar negeri pembangunan Norwegia. Kondisi lingkungan yang memuaskan membantu memajukan stabilitas dan keamanan. Lingkungan yang sehat dan beragam penting untuk mengentaskan kemiskinan dan mencapai pembangunan yang berkesinambungan yang bermanfaat bagi semua orang di seluruh dunia. Norwegia mendukung penuh upaya negara-negara dengan kawasan hutan hujan tropis besar, seperti Indonesia, Brasil, dan Republik Kongo, untuk menurunkan laju emisinya. Karena Norwegia berpendapat hutan memiliki peran yang sangat signifikan mencegah laju perubahan iklim. Di antara komitmen negara maju, komitmen Norwegia lah yang paling jelas dengan rencana penurunan emisi $30 \%$ dari level tahun 1990 sampai tahun 2020. Komitmen Norwegia pada isu lingkungan hidup ini dituangkan dengan meratifikasi Protokol Kyoto. Norwegia kemudian juga turut serta dalam skema REDD.

Di bulan Oktober 2009, Presiden Susilo Bambang Yudhoyono menyatakan komitmen untuk mengurangi emisi $\mathrm{CO}_{2}$ Indonesia sebesar $26 \%$ hingga $41 \%$ di tahun 2020 jika mendapat dukungan internasional. Ini merupakan komitmen terbesar yang pernah diutarakan oleh sebuah negara berkembang. Indonesia telah menetapkan target absolut dan Norwegia ingin membantu upaya pemerintah Indonesia mencapai komitmen tersebut.

Alasan mengapa Norwegia mengutarakan komitmennya untuk memberi hibah 1 miliar USD adalah sebagai negara industri yang termasuk dalam Annex 1 pada Protokol Kyoto, Norwegia memiliki kewajiban mengikat untuk menurunkan emisi karbon dalam negerinya, terutama karena tingkat penggunaan energi fosil, industrialisasi, dan transportasi yang sangat tinggi. Negara Annex 1 merupakan negara maju yang sektor industrinya berkembang sejak revolusi industri dan dianggap bertanggung jawab atas peningkatan emisi gas global.
Terkait dengan ketidakmampuan Norwegia untuk menurunkan emisi karbon, maka negara ini bersedia memberikan hibah kepada negara berkembang, salah satunya adalah Indonesia. Di bulan Mei 2010 disahkan kesepakatan antara Indonesia dengan Norwegia yang tertulis dalam LoI (Letter of Intent) yang ditandatangani di Oslo, Norwegia.

\subsection{Rumusan Masalah}

Berdasarkan latar belakang masalah diatas, untuk memudahkan penulis dalam melakukan pembahasan, penulis merumuskan masalah sebagai berikut:

"Bagaimana Kerjasama Indonesia - Norwegia Melalui Skema Reducing Emission From Deforestation and Forest Degradation (REDD+) Dalam Upaya Penyelamatan Hutan Indonesia"

Rumusan Masalah Minor:

1. Faktor apa yang menjadi latar belakang kerjasama yang dilakukan oleh Pemerintah Indonesia dan Norwegia melalui kerangka REDD+ dalam upaya penyelamatan hutan Indonesia?

2. Program apa saja yang dilakukan Pemerintah Indonesia - Norwegia melalui kerangka REDD+ dalam upaya penyelamatan hutan Indonesia?

3. Kendala apa saja yang dialami program REDD+ dalam upaya penyelamatan hutan Indonesia?

4. Sejauh mana tingkat keberhasilan program REDD+ dan prospek kerjasama Indonesia Norwegia melalui kerangka REDD+ dalam upaya penyelamatan hutan Indonesia?

\subsection{Maksud dan Tujuan}

Maksud dilakukannya penelitian ini adalah untuk menganalisis kerjasama yang dilakukan oleh Indonesia dan Norwegia melalui skema REDD+ dalam upaya penyelamatan hutan Indonesia.

Adapun tujuan dari penelitian dan penulisan skripsi ini adalah :

1. Penelitian dalam penulisan skripsi ini diharapkan dapat memperkaya pemanahaman tentang REDD+ yang menjadi salah satu instrument penyelesaian permasalahan dalam mengurangi emisi gas rumah kaca dan faktor yang melatarbelakangi terbentuknya kerjasama antara pemerintah Indonesia dan pemerintah Norwegia dalam kerangka REDD+ dalam rangka penyelamatan hutan Indonesia; 
2. Mengetahui, memahami, dan meneliti program apa saja yang telah dilakukan pemerintah Indonesia dan pemerintah Norwegia melalui kerangka REDD dalam rangka penyelamatan hutan Indonesia;

3. Mengetahui, memahami, dan meneliti kendala-kendala dalam skema REDD+ dalam upaya penyelamatan hutan Indonesia;

4. Mengetahui, memahami, dan meneliti sejauh mana tingkat keberhasilan program REDD+ dan prospek dari kerjasama yang tengah dijalankan oleh pemerintah Indonesia dan pemerintah Norwegia dalam upaya menyelamatkan hutan Indonesia dari kerusakan meskipun terdapat kendala didalam pelaksanaan kerjasama tersebut.

\subsection{Kegunaan Penelitian}

\subsubsection{Kegunaan Teoritis}

Penelitian ini diharapkan dapat berguna untuk memperkaya pengetahuan mengenai kerjasama

\section{Kajian Pustaka dan Kerangka Pemikiran}

\subsection{Tinjauan Pustaka}

Penelitian sebelumnya yang penulis jadikan acuan dalam tinjauan pustaka adalah skripsi Sigit Winarto tahun 2007, yang berjudul Latar Belakang Diterimanya Proposal Reducing Emission From Deforestation And Forest Degradation (REDD) Indonesia Oleh Norwegia. Karya ini penulis rujuk karena merupakan satu dari sedikit kajian yang membahas kerjasama yang dilakukan oleh Indonesia dan Norwegia dalam kerangka REDD. Winarto membahas bagaimana REDD diharapkan dapat menjadi salah satu instrumen penyelesaian permasalahan dalam mengurangi emisi gas rumah kaca.

Winarto hanya memfokuskan penelitiannya pada diterimanya proposal REDD dari Indonesia oleh Norwegia tanpa membahas dampaknya terhadap upaya penyelamatan hutan Indonesia, sebagaimana yang akan dilakukan penulis. Winarto menjelaskan secara detail, terperinci, sekaligus sistematis sebab-musabab diterimanya proposal REDD oleh pemerintah Norwegia. Winarto juga menyelipkan mengenai kerjasama serupa dengan Brasil yang dilakukan oleh Norwegia dalam payung REDD. Dan menjabarkan perbedaan-perbedaan diantara kedua bentuk kerjasama dengan kedua negara tersebut. bilateral dalam mengatasi suatu permasalahan. Khususnya kerjasama antara Indonesia - Norwegia di dalam kerangka Reducing Emission From Deforestation and Forest Degradation (REDD+) dalam upaya meminimalisir kerusakan hutan Indonesia.

\subsubsection{Kegunaan Praktis}

Hasil dari penelitian ini diharapkan dapat berguna sebagai bahan tambahan informasi dan studi empiris bagi para penstudi Ilmu Hubungan Internasional yang menaruh minat terhadap kerjasama untuk menanggulangi kerusakan hutan khususnya hutan Indonesia. Serta diharapkan dapat sebagai masukkan bagi pemerintah dan pemangku kepentingan untuk meneliti lebih lanjut agar program kehutanan yang dicanangkan pemerintah dapat lebih terarah, tepat sasaran dan sebagai bahan pertimbangan serta evaluasi program

penelitian.

Winarto menggunakan teori Rational Choice yang disampaikan oleh James S. Coleman. Teori ini tentang bagaimana suatu negara dalam bertindak mengambil suatu keputusan yang didasarkan pada pilihan-pilihan rasional dan terdapatna mekanisme serta pertimbangan untung rugi menjadikan teori ini dominan dalam aplikasinya dan sangat cocok untuk menjadi salah satu pilihan dalam pengambilan keputusan. Norwegia memiiki kewajiban mengikat untuk menurunkan emisi karbon di dalam negerinya. Namun dengan adanya ketidakmampuan Norwegia untuk menurunkan emisi karbon dari dalam negaranya, maka negara ini bersedia memberikan hibah kepada negara berkembang yang memiliki sumber daya hutan untuk mengurangi laju deforestasi dan kerusakan hutan, salah satunya Indonesia.

Sementara itu, Arild Angelsen yang merupakan peneliti Center For International Forestry Research (CIFOR) dalam publikasi yang berjudul Menganalisis REDD+: Tantangan dan Pilihan ditahun 2012, mengkaji bagaimana skema yang didukung oleh Persatuan Bangsa Bangsa (PBB) ini menawarkan berbagai gagasan mengenai bagaimana meningkatkannya sebagai salah satu instrumen dalam pengurangan emisi karbon.

Ketika REDD+ telah bergerak dari sebuah gagasan kedunia nyata, tantangannya telah meningkat. Berbagai tantangan tersebut bersifat praktis atau politis, dari bagaimana cara mengukur dan memantau emisi 
karbon yang dihindarkan dengan membiarkan sebuah hutan tetap tegak, sampai memutuskan siapa yang mendapatkan uang yang dihasilkan oleh REDD+, sampai mencapai koordinasi diantara tingkatan tata kelola lokal, regional, nasional dan internasional.

Menganalisis REDD+ memperdebatkan bahwa untuk mewujudkan potensi sepenuhnya sebagai sarana untuk memitigasi terhadap perubahan iklim, REDD+ memerlukan sebuah perubahan transformasional dalam cara kita menganggap hutan.

\subsection{Kerangka Pemikiran}

\subsubsection{Hubungan Internasional}

Pengertian Hubungan Internasional menurut Charles Mc Clelland, yang dikutip oleh Perwita dan Yani adalah sebagai berikut:

"Hubungan Internasional merupakan studi tentang interaksi antara jenis-jenis kesatuan tertentu, termasuk studi tentang keadaankeadaan yang relevan yang mengelilingi interaksi” (Perwita dan Yani, 2005:4).

Ilmu Hubungan Internasional merupakan ilmu dengan kajian interdisipliner dengan pengertian ilmu ini dapat menggunakan berbagai teori, konsep, dan pendekatan dari bidang-bidang ilmu lain dalam mengembangkan kajian-kajiannya. Dewasa ini, kajian dan ruang lingkup Hubungan Internasional mengalami perkembangan yang cukup pesat. Hubungan Internasional yang pada awalnya hanya mempelajari tentang hubungan antar negara-negara yang berdaulat saja, telah mengalami pergeseran, dimana, muncul aktor-aktor lain dalam ilmu Hubungan Internasional juga mempunyai peranan yang penting.

Terdapat dua isu tradisional utama dalam Hubungan Internasioanl yakni isu keamanan nasional dan ekonomi global, isu lingkungan hidup kemudian muncul sebagai isu ketiga yang memiliki tingkat urgensi yang sama dengan kedua isu yang disebutkan sebelumnya (Porter, 2000: 1). Hal ini lebih dikarenakan isu-isu low politics (ekonomi, lingkungan hidup, sosial, dan lain-lain) tidak mendapatkan perhatian yang relevan dari masyarakat dunia era Perang Dingin (Cold War), karena perhatian dunia dewasa ini hampir seluruhnya terfokus kepada isu-isu seputar politik, keamanan nasional, dan persaingan ideologi (isu-isu high politics) (Scheurs, 2003:5-6).

Salah saty konsep umum yang terdapat di dalam Hubungan Internasional, yaitu kerjasama.

Dalam Hubungan Internasional dikenal apa yang dinamakan kerjasama internasional. Dalam suatu kerjasama internasional bertemu berbagai macam kepentingan nasional dari berbagai negara dan bangsa yang tidak dapat dipenuhi didalam negerinya sendiri (Perwita Dan Yani, 2005:29-34).

\subsubsection{Politik Luar Negeri}

Politik luar negeri merupakan suatu perangkat formula nilai, sikap, arah serta sasaran untuk mempertahankan, mengamankan, dan memajukan kepentingan nasional di dalam percaturan dunia internasional (Perwita \& Yani, 2005:7).

Politik luar negeri terdiri dari dua elemen, yaitu tujuan nasional yang akan dicapai dan alat-alat untuk mencapainya. Interaksi antara dua tujuan nasional dengan sumber-sumber untuk mencapainya merupakan subjek kenegaraan yang abadi (Couloumbis \& Wolfe, 1999:126).

\subsubsection{Kerjasama Internasional}

Pola interaksi Hubungan Internasional tidak dapat dipisahkan dengan segala bentuk interaksi yang berlangsung dalam pergaulan masyarakat internasional, baik oleh pelaku negara (state actor) maupun oleh pelaku bukan negara (non-state actor). Pola hubungan atau interaksi ini dapat berupa kerjasama (cooperation), persaingan (competition), dan pertentangan (conflict) (Rudy, 2003:2). Kerjasama merupakan serangkaian hubungan yang tidak didasari kekerasan atau paksaan dan disahkan secara hukum.

Kerjasama bermula karena adanya keanekaragaman masalah nasional, regional maupun global yang muncul sehingga diperlukan adanya perhatian lebih dari satu negara, kemudian masingmasing pemerintah saling melakukan pendekatan dengan membawa usul penanggulangan masalah, melakukan tawar-menawar, atau mendiskusikan masalah, menyimpulkan bukti-bukti teknis untuk membenarkan satu usul yang lainnya, dan mengakhiri perundingan dengan suatu perjanjian atau saling pengertian yang dapat memuaskan semua pihak (Holsti, 1987:651).

Karena dalam penelitian ini meneliti mengenai dua negara yang berinteraksi, maka penulis akan membahas mengenai perjanjian bilateral. Kerjasama bilateral adalah kerjasama yang diadakan oleh dua buah negara untuk mengatur kepentingan kedua belah pihak (Rudy, 2002:127). Perjanjian Bilateral akan muncul bila dua negara saling sepakat akan adanya kepentingan yang sama. Jika bentuk perjanjian berupa kerjasama dan lingkupnya hanya terbatas pada dua negara saja maka kerjasama itu memiliki kecenderungan untuk bertahan lama, perlu diketahui, kerjasama tidak akan dilakukan bila suatu negara bisa 
mencapai tujuannya sendiri. Sehingga dalam hal ini terlihat bahwa kerjasama hanya akan terjadi, karena adanya saling ketergantungan antar negara-negara untuk mencapai kepentingan nasionalnya masingmasing.

\subsubsection{Lingkungan Hidup}

\subsubsection{Pengertian Lingkungan Hidup}

Menurut Undang-Undang No. 23 Tahun 1997, Lingkungan hidup didefinisikan sebagai kesatuan ruang dengan semua benda, daya, keadaan, dan makhluk hidup, termasuk manusia dan perilakunya, yang mempengaruhi kelangsungan kehidupan dan kesejahteraan manusia serta mahkluk hidup lain (Siahaan, 2004: 56).

Lingkungan hidup menjadi salah satu isu penting dalam Hubungan Internasional disamping dua isu lainnya, yakni demokrasi dan hak asasi manusia (HAM). Ini berarti permasalahan lingkungan hidup dihadapi bukan hanya di negara-negara berkembang saja, namun negara maju pun menghadapi permasalahan yang sama. Hal ini disebabkan karena masalah lingkungan hidup berpangkal dari sumber utama yang sama yakni kegiatan pembangunan. Pembangunan pada dasarnya memanfaatkan sumber daya alam sebagai upaya meningkatkan kesejahteraan manusia. Pemanfaatan sumber daya alam yang tidak memperhatikan daya dukung lingkungan menyebabkan kerusakan yang mengancam eksistensi manusia itu sendiri. Berbagai kerusakan lingkungan hidup seperti menipisnya lapisan ozon, global warming, perubahan iklim, merosotnya keaneka ragaman hayati, degradasi tanah, pencemaran udara, dan lain sebagainya mendorong kearah pemikiran pentingnya lingkungan hidup menjadi pertimbangan dalam kebijakan pembangunan (http://www.psil.undip.ac.id/index.php ?option=com_content $\&$ view=article $\&$ id=122\&Itemid= 27 diakses pada tanggal 14-04-2012).

Salah satu masalah krusial dalam bidang lingkungan hidup adalah pada sektor kehutanan. Definisi hutan menurut Undang-Undang No. 41 Tahun 1999 tentang kehutanan, yaitu hutan sebagai suatu kesatuan ekosistem berupa hamparan berisi sumber daya alam yang didominasi pepohonan dalam persekutuan alam lingkungannya, yang satu dengan yang lainnya tidak dapat dipisahkan. Keberlangsungan hutan merupakan hal yang penting demi generasi selanjutnya. Rusaknya hutan dapat menyebabkan berbagai pemasalahan seperti perubahan iklim, hilangnya keragaman biologi dan penyebaran zat kimia berbahaya ke lingkungan.
Dibutuhkan kerangka kerjasama lingkungan internasional yang mampu untuk merencanakan solusi yang baik dalam menghadapi tantangan lingkungan global yang dihadapi oleh negara-negara di dunia. Kebijakan manajemen lingkungan dan sumber daya merupakan komponen penting dari kebijakan kerjasama luar negeri dan pembangunan. Kondisi lingkungan yang baik membantu memajukan stabilitas dan keamanan suatu negara atau kawasan (http://www.norwegia.or.id/?About_Norway/=PolitikLuar-Negeri/iklim-dan-lingkungan-hidup-/cooperation/ diakses pada tanggal 18-04-2012).

\subsubsection{Bantuan Luar Negeri}

Bantuan luar negeri (foreign aid) diartikan sebagai tindakan-tindakan masyarakat atau lembagalembaga terhadap masyarakat atau lembaga-lembaga lain di luar negeri dengan maksud sekurang-kurangnya untuk membantu" (Ikbar, 2007:188).

Program bantuan luar negeri ini bersifat saling menguntungkan. Pihak penerima memperoleh bantuan baik itu berupa dana, perlengkapan, maupun pengetahuan yang diharapkan mampu mengikuti dinamika ekonomi modern, stabilitas politik dan keamanan militer. Saat ini masalah-masalah pembangunan dan kerjasama ekonomi menjadi agenda utama dalam politik internasional. Teknik pemberian bantuan dapat dilakukan secara bilateral maupun multilateral. Dengan kata lain, pemberian bantuan luar negeri dapat dilakukan antar pemerintah (government to government) atau melalui lembaga keuangan internasional seperti IMF dan World Bank.

Terdapat empat motivasi dar negara para pemberi bantuan atau negara donor dalam memberikan bantuan, diantaranya:

\section{Motivasi kemanusiaan}

2. Motivasi politik

3. Motivasi keamanan nasional

4. Motivasi yang berkaitan dengan kepentingan nasional negara donor (Perwita \& Yani, 2005:84).

Apabila dikaitkan dengan motivasi bantuan luar negeri yang dikemukakan oleh Perwita dan Yani dengan pemberian insentif yang diberikan oleh pemerintah Norwegia kepada pemerintah Indonesia melalui skema REDD+ dalam upaya penyelamatan hutan Indonesia sebagaimana yang diteliti dalam penelitian ini adalah motivasi yang berkaitan dengan kepentingan nasional Norwegia, dimana Norwegia memiliki hutang karbon yang harus dibayarkan oleh negara nya sebagai negara Annex 1 dalam Protokol 
Kyoto, namun Norwegia tidak memiliki kemampuan untuk melakukan hal tersebut dari dalam negaranya. Maka dari itu, pemerintah Norwegia memberikan dana hibah sebesar 1 miliar USD (Dollar Amerika Serikat) kepada Indonesia.

Selain itu terdapat pula motivasi politik, dimana Norwegia dengan memberikan hibah tersebut

\section{Objek dan Metode Penelitian}

\subsection{Objek Penelitian}

\subsubsection{Hutan Indonesia}

Hutan adalah suatu kesatuan ekosistem berupa hamparan lahan berisi sumber daya alam hayati yang didominasi pepohonan dalam persekutuan alam lingkungannya, yang satu dengan lainnya tidak dapat dipisahkan. Salah satu fungsi hutan adalah sebagai penyerap karbon dioksida. Hutan juga merupakan rumah bagi duapertiga dari spesies tanaman dan binatang di dunia.

Secara garis besar, fungsi hutan dapat dibedakan menjadi empat. Pertama fungsi Hutan Konservasi, kedua Hutan Cadangan, ketiga Hutan Lindung, dan keempat fungsi hutan sebagai Hutan Produksi, berikut ini penjelasan dari keempat fungsi hutan tersebut:

1. Hutan Konservasi

Hutan konservasi merupakan kawasan hutan dengan ciri khas tertentu, yang mempunyai fungsi pokok pengawetan keanekaragaman tumbuhan dan satwa serta ekosistemnya.

2. Hutan Cadangan

Hutan cadangan yaitu hutan yang dijadikan sebagai lahan pertanian dan pemukiman penduduk.

3. Hutan Lindung

Hutan lindung difungsikan sebagai perlindungan sistem penyangga kehidupan untuk mengatur tata air dan penjaga keteraturan air dalam tanah (fungsi hidrolisis), mencegah banjir, mengendalikan erosi, menjaga tanah agar tidak terjadi erosi serta untuk mengatur iklim (fungsi klimatologis), sebagai penanggulangan pencemaran udara seperti karbon dioksida $\left(\mathrm{CO}_{2}\right)$ dan karbon monoksida $(\mathrm{CO})$, mencegah intrusi air laut dan memelihara kesuburan tanah.

4. Hutan Produksi menjadikan negara ini mendapat pujian dari dunia internasional sebagai negara yang sangat berkomitmen pada isu lingkungan hidup serta menjadi negara Annex 1 yang terdepan dalam berbagai forum kerjasama lingkungan internasional.

Hutan produksi merupakan hutan yang dapat dikelola untuk memproduksi hasil hutan dan menghasilkan sesuatu yang bernilai ekonomi. Hutan produksi dapat dikategorikan menjadi dua golongan, yakni hutan rimba dan hutan budidaya. Hutan rimba adalah hutan yang alami sedangkan hutan budidaya adalah hutan yang sengaja dikelola manusia yang biasanya terdiri dari satu jenis tanaman saja.

Hutan memiliki manfaat yang sangat banyak bagi manusia maupun makhluk hidup lain disekitarnya. Diantara manfaat-manfaat tersebut dibagi menjadi dua, yakni manfaat langsung serta manfaat tidak langsung. Manfaat langsung yang disediakan hutan adalah sebagai sumber bahan/konstruksi bangunan, sumber bahan pembuatan perabot rumah, sumber bahan pangan, sumber untuk mendapatkan protein, sumber pembuatan pendukung fasilitas pendidikan, sumber bahan bakar, sumber oksigen, sumber pendapatan, sumber obat-obatan dan habitat satwa.

Manfaat tidak langsung yang diperoleh dari hutan antara lain sebagai pengatur sistem tata air, kontrol pola iklim, kontrol pemanasan bumi, ekowisata, laboratorium plasma nutfah, pusat pendidikan dan penelitian, sumber bahan pendukung industri-industri kimia, menghasilkan devisa melalui program Clean Development Mechanism (CDM) maupun Reducing Emission From Deforestation And Forrest Degradation (REDD) (http://pengertiandefinisi.blogspot.com/2010/ 10/manfaat-hutan.html diakses pada tanggal 19-07-2013).

Kerusakan hutan dan lahan akan mengakibatkan rusaknya fungsi konservasi dari hutan telah menimbulkan punahnya keanekaragaman tumbuhan dan satwa serta ekosistemnya. Selain itu berakibat pula terhadap daya serap tanah terhadap air yang semakin menurun, hal ini dapat mengakibatkan banjir dan tanah longsor di waktu musim hujan. Dalam tingkat yang lebih kritis, kerusakan hutan yang berakibat terjadinya degradasi dan deforestasi hutan dapat menyebabkan kegundulan pada hutan yang mengakibatkan hilangnya fungsi hutan sebagai paru-paru dunia sebagai penyerap 
karbon yang dapat mengurangi efek dari global warming.

Panel Antar-Pemerintah tentang Perubahan Iklim (IPCC) dalam laporannya tahun 2007 memperkirakan bahwa deforestasi dan degradasi hutan berkontribusi kurang lebih $17 \%$ dari keseluruhan jumlah emisi gas rumah kaca, lebih besar dari sektor transportasi global. Deforestasi dan degradasi hutan menempati urutan keempat setelah sektor energi global sebesar $26 \%$ dan sektor industri sebesar $19 \%$.

Indonesia merupakan negara dengan luas hutan terbesar ketiga didunia. Luas kawasan hutan dan perairan Indonesia seluas 136.833.213,98 Ha. Namun dalam satu dekade terakhir Indonesia telah kehilangan hingga 40\% dari seluruh luas hutannya. Laju degradasi hutan dan deforestasi di wilayah Indonesia mencapai 1,5 juta $H a$ sampai 2,8 juta $H a$ per tahun (http://www.antaranews.com/print/31978/degradasi-

hutan-10-tahun-terakhir-menc apai-dua-juta-hektar diakses pada tanggal 21-06-2013). Kerusakan hutan tersebut menimbulkan lahan kritis yang keadaan fisiknya demikian rupa sehingga lahan tersebut tidak dapat berfungsi secara baik sesuai dengan peruntukkannya sebagai media produksi maupun sebagai media tata air.

Kerusakan hutan merupakan masalah yang serius yang jika tidak ditangani dengan baik dan serius akan menimbulkan dampak yang besar bagi perekonomian dan lingkungan. Kerusakan hutan dan lahan pada dasarnya dipengaruhi oleh berbagai faktor penyebab, baik yang disebabkan oleh ulah manusia dan alam.

Faktor-faktor penyebab terjadinya kerusakan hutan di Indonesia antara lain adalah sebagai berikut:

1. Penebangan hutan tanpa upaya rehabilitasi yang optimal

Pemberian ijin Hak Pengusahaan Hutan kepada perusahaan-perusahaan mendorong kegiatan pemanfaatan potensi hutan. Pemberian ijin ini seharusnya diikuti dengan upaya rehabilitasi atau upayauoaya lainnya yang menjamin kelestarian hutan di wilayah ijin pengusahaan hutan. Ketimpangan antara upaya pelestarian dan produksi telah meningkatkan penggundulan dan kerusakan hutan.

2. Kebakaran hutan

Kebakaran hutan dapat disebabkan karena ulah masyarakat dan/atau pengusaha yang membutuhkan lahan untuk areal pemukiman dan/atau pertanian atau perkebunan. Masyarakat dan pengusaha membuka lahan untuk melakukan pembersihan lahan dengan cara membakar lahan yang berpotensi merusak lingkungan, menambah kerusakan hutan dan mencemari udara.

3. Pembalakan liar (illegal logging)

Penjarahan hutan tetap berlaku dan tetap belangsung hingga sekarang. Hal ini terjadi antara lain karena adanya ketimpangan pasoka dan permintaan, lemahnya penegakkan hukum, dan masalah kesejahteraan masyarakat di dalam dan di sekitar hutan.

4. Alih fungsi hutan menjadi areal pertanian dan perkebunan

Pertumbuhan ekonomi dan jumlah penduduk mendorong munculnya kebutuhan akan lahan untuk areal pertanian, perkebunan dan pemukiman. Meningkatnya peralihan fungsi hutan menjadi lahan-lahan non kehutanan yang menyebabkan peningkatan jumlah penggundulan dan kerusakan hutan dan lahan (http://www.environmentalauditing.org

/Portals/0/AuditFiles/Audit\%20of\%20\%20

Commodity\%20Plants\%20Forest.pdf diakses pada tanggal 04-05-2012).

Di Indonesia pengelolaan dan pembangunan lingkungan hidup relatif belum terlalu lama digulirkan. Namun, dalam waktu yang singkat tersebut Indonesia telah banyak berbuat untuk mengelola lingkungan hidupnya. Hasil utama pengembangan lingkungan hidup ini nampak pada munculnya kesadaran dan kepedulian dikalangan masyarakat. Kebijakan Lingkungan Hidup Indonesia dituang kedalam pasal Undang-Undang No. 23 tahun 1997, mengenai pengelolaan, pelestarian, dan perlindungan lingkungan.

Sasaran pengelolaan lingkungan hidup Indonesia sesuai dengan Pasal 4 dalam UndangUndang No. 23 tahun 1997 adalah sebagai berikut:

1. Tercapainya keselarasan, keserasian, dan keseimbangan antara manusia dan lingkungan hidup;

2. Terwujudnya manusia Indonesia sebagai insan lingkungan hidup yang memiliki sikap dan tindak melindungi dan membina lingkungan

hidup; 
3. Terjaminnya kepentingan generasi masa kini dan generasi masa depan;

4. Tercapainya kelestarian fungsi lingkungan hidup;

5. Terkendalinya pemanfaatan sumber daya secara bijaksana;

6. Terlindunginya Negara Kesatuan Republik Indonesia terhadap dampak usaha dan/atau kegiatan di luar wilayah negara yang menyebabkan pencemaran dan/atau perusakan lingkungan hidup.

\subsubsection{Kebijakan Lingkungan Hidup Norwegia}

Kerajaan Norwegia adalah sebuah negara di Semenanjung Skandinavia bagian ujung barat yang berbatasan dengan Swedia, Finlandia dan Rusia. Norwegia adalah sebuah negara demokrasi konstitusionil dibagian utara Eropa dengan penduduk sebanyak 4.9 juta jiwa. Norwegia memiliki luas area sebesar $385.525 \mathrm{Km}^{2}$ dan beribukota di Oslo. Terdaftar sebagai salah satu negara terkaya di dunia, norwegia juga menduduki peringkat tertinggi dalam hal standar hidup, usia rata-rata, dan standar kesehatan secara umum. Negara ini memiliki cadangan minyak bumi, gas alam, mineral, makanan laut, air segar yang luas. Norwegia juga penghasil minyak dan gas alam perkapita terbesar diluar Timur Tengah.

Bentangan alam Norwegia pada umumnya kasar dan bergunung-gunung, sebagian besar tertutup oleh gletser. Di Norwegia jarang sekali ditemui hutan seperti pada negara tropis, yang berguna untuk menyerap karbon akibat dari aktivitas industrinya. Padahal walaupun sebagai negara industri maju, Norwegia juga memiliki prioritas akan permasalahan lingkungan hidup, maka dari itu Norwegia memerlukan kerjasama dengan negara pemilik pohon untuk menjalankan kewajibannya menurunkan emisi gas buang industrinya.

Norwegia merupakan negara yang berkomitmen pada isu lingkungan hidup. Salah satu tujuan utama kebijakan pembangunan negara ini adalah memajukan manajemen yang solid akan lingkungan hidup global dan keanekaragaman biologi. Pemerintah Norwegia secara aktif bekerja untuk menstabilkan konsentrasi gas rumah kaca di lapisan udara, untuk mencapai tingkat yang akan mencegah gangguan berbahaya yang disebabkan manusia bagi sistem iklim. Karena negara ini berpendapat bahwa kondisi lingkungan yang sehat dan beragam penting untuk mengentaskan kemiskinan dan mencapai pembangunan yang berkesinambungan bagi semua orang di seluruh dunia serta akan membantu mewujudkan stabilitas dan keamanan negara.

Kegiatan kerjasama pembangunan yang dilakukan Norwegia dengan negara lain bertujuan untuk memperbaiki keadaan lingkungan negara mitra dan mencegah degradasi lingkungan global. Kebijakan manajemen lingkungan dan sumber daya merupakan komponen penting dari kebijakan kerjasama luar negeri dan pembangunan Norwegia.

Area yang menjadi prioritas kerjasama pembangunan Norwegia dan kerjasama dengan negara berkembang meliputi:

1. Pengurangan polusi;

2. Sistem produksi yang berkesinambungan;

3. Konservasi penggunaan keragaman biologi yang berkesinambungan;

4. Pemeliharaan peninggalan budaya.

Norwegia mendukung penuh upaya negaranegara dengan kawasan hutan hujan tropis besar, seperti Indonesia, Brasil, dan Republik Kongo, untuk menurunkan laju emisinya. Hutan memiliki peran yang sangat signifikan mencegah laju perubahan iklim. Di antara komitmen negara maju, komitmen Norwegia lah yang paling jelas dengan rencana penurunan emisi $30 \%$ dari level tahun 1990 sampai tahun 2020. Komitmen Norwegia pada isu lingkungan hidup ini dituangkan dengan meratifikasi Protokol Kyoto. Pertumbuhan ekonomi di Norwegia sangat tinggi maka dalam Protokol Kyoto dimasukkan kedalam kategori negara Annex 1. Norwegia kemudian juga turut serta dalam skema REDD. Departemen Lingkungan Hidup Norwegia telah menandatangani perjanjian lingkungan hidup, masing-masing dengan Indonesia, Afrika Selatan, Brazil, dan China (http://www.norwegia.or.id/About_Norway/PolitikLuar-Negeri/Iklim-dan-lingkungan-hidup/cooperation/ diakses pada tanggal 01-05-2012).

\subsubsection{Hubungan Indonesia - Norwegia}

Hubungan diplomatik Indonesia - Norwegia dimulai sejak Januari 1951, namun pada saat itu masih merupakan wilayah perangkapan KBRI Stockholm, Swedia sampai tahun 1962. Pada periode 1962-1981 Norwegia dirangkap oleh KBRI Kopenhagen, Denmark, dan baru pada 17 September 1981 KBRI Oslo resmi dibuka.

Dalam beberapa tahun terakhir, hubungan kedua negara mengalami peningkatan yang signifikan. Berikut beberapa kerjasama antara Pemerintah Indonesia dan Pemerintah Kerajaan Norwegia, menurut Kementerian Luar Negeri Republik Indonesia: 
1. Persetujuan mengenai peningkatan dan perlindungan atas penanaman modal (November 1969)

2. Konvensi mengenai penghindaran pajak berganda dan pencegahan pengelakan pajak atas pajak penghasilan dan atas moda (Juli 1988)

3. Persetujuan mengenai peningkatan dan perlindungan atas penanaman modal secara timbal balik (November 1991)

4. Memorandum saling pengertian mengenai prosedur konsultasi untuk pengembangan kerjasama antara Indonesia dan Norwegia (September 1995)

5. Memorandum saling pengertian antara Badan Penanggulangan Dampak Lingkungan (BAPEDAL) dan Badan Kerjasama Pembangunan Norwegia tentang proyek kebersihan produksi di Propinsi Riau, Indonesia (Mei 1998)

6. Kerjasama kelautan dan perikanan (Januari 2006)

7. Deklarasi mengenai isu-isu perubahan iklim dan energi (Maret 2007)

8. Kerjasama industri gas (Oktober 2011)

9. Kerjasama aquaculture (Oktober 2011)

Selain itu, kedua negara juga mengembangkan kemitraan dalam isu-isu internasional penting, antara lain dalam Seven Nations Initiative (7NI) di bidang nuclear non-proliferation, upaya pencapaian Millenium Development Goals 4 dan 5 (mencegah kematian anak dan ibu melahirkan) yang dikemas dalam keanggotaan "Sherpa Group", menjadi cohost dalam inter-media dialogue, serta kemitraan dalam inisiatif health and foreign policy.

Dalam pertemuan G-20 di Pittsburgh, Amerika Serikat di tahun 2009, Presiden Republik Indonesia, Susilo Bambang Yudhoyono melontarkan janji untuk mengurangi emisi Indonesia hingga $26 \%$ pada tahun 2020 jika mendapat dukungan internasional. Ini merupakan janji terbesar yang pernah diucapkan oleh seorang Kepala Negara dari negara berkembang (http://ri-norwegia-sepakati-redd+-1-miliar-dolaras.htm diakses pada tanggal 12-05-2012). Presiden Yudhoyono memperlihatkan kemauan dan potensi kepemimpinan untuk mengurangi dampak dari perubahan iklim. Penetapan target absolut ini langsung disambut positif oleh negara-negara lain. Norwegia menjadi negara terdepan yang menunjukkan apresiasinya dan menyatakan ingin membantu upaya Pemerintah Indonesia mencapai komitmen tersebut.

Kedua negara membawa hubungan bilateral diantara keduanya ke tingkat yang lebih baik lagi. Dalam rangka menyambut janji Presiden Yudhoyono dalam pertemua G-20 Pittsburgh, Norwegia kemudian menjanjikan akan memberi dana sebesar 1 miliar USD bagi upaya untuk mengurangi emisi gas dan penggundulan hutan di Indonesia dalam kerangka REDD+.Norwegia mendukung penuh upaya negaranegara dengan kawasan hutan hujan tropis besar seperti Indonesia untuk menurunkan laju emisinya. Karena Norwegia berpendapat hutan memiliki peran yang sangat signifikan untuk mencegah laju perubahan iklim.

Juga sebagai negara Industri yang termasuk keadalam negara Annex 1 pada Protokol Kyoto, Norwegia memiliki kewajiban untuk menurunkan emisi karbon dalam negerinya, terutama karena tingkat penggunaan energi fosil, industrialisasi, dan transportasi yang sangat tinggi. Terkait dengan ketidakmampuan Norwegia untuk menurunkan emisi karbon, maka salah satu jalan adalah dengan memberikan hibah insentif kepada negara berkembang pemilik hutan. Pemberian Hibah ini sejalan dengan kesepakatan COP.

Indonesia merupakan salah satu negara di dunia yang memiliki kekayaan biologi yang sangat beragam, dengan hutan tropis yang memainkan peran penting dalam iklim global. Tujuan dari kerjasama lingkungan ini adalah untuk menghasilkan rencana kerja untuk manajemen lingkungan dan sumber daya alam yang menggunakan pendekatan ekosistem.

Pada tanggal 26 Mei 2010, disahkanlah Letter of Intent (LoI) antara Pemerintah Indonesia dengan Pemerintah Kerajaan Norwegia, yang ditandatangani oleh Menteri Luar Negeri Indonesia Marty Natalegawa dan Menteri Lingkungan Hidup Norwegia Erik Solhein, yang turut disaksikan oleh Kepala Pemerintahan kedua Negara, yakni Presiden Indonesia Susilo Bambang Yudhoyono dan Perdana Menteri Norwegia Jens Stoltenberg di Gedung Government Guest House, Oslo, Norwegia (http://forum.kompas.com/nasional/ 29986terimakasih-banyak-kepada-kerajaan-norwegia-danselamat-untuk-pemerin tah-indonesia.html diakses pada 12-05-2012).

Kerjasama ini disepakati dibagi dalam tiga fase. Pertama, fase persiapan pada bulan Juli-Desember 2010, yakni membuat rencana aksi nasional, 
membentuk lembaga pengelolaan dana hibah (trust fund) dan lembaga pengukur, pelaporan, dan verifikasi (measurement, reporting, and verification/MRV) untuk memantau keberhasilan, serta menentukan Provinsi sebagai proyek percontohan. Fase kedua, Januari 2011Desember 2013, yang dilakukan adalah mengoperasikan lembaga pembiayaan, moratorium izin baru konversi hutan alam primer dan gambut, menyusun database hutan rusak untuk memfasilitasi kegiatan ekonomi, penegakan hukum penebangan kayu illegal dan perdagangan kayu gelondongan. Selanjutnya fase ketiga, Januari 2014, adalah pelaksanaan moratorium secara nasional. Besaran insentif yang akan diberikan oleh Norwegia kepada Indonesia hingga sebesar 1 milliar USD (Dollar Amerika Serikat), sesuai dengan keberhasilan yang dicapai oleh Indonesia sesuai dengan fase-fase yang tertera dalam LoI tersebut. Perhitungan tingkat keberhasilan ini akan ditentukan dengan menggunakan mekanisme MRV. Dana yang diberikan oleh Norwegia akan dikelola oleh Satgas REDD bidang pengelolaan dana hibah dengan menggandeng UNDP (United Nations Development Programme) sebagai badan internasional yang bertugas untuk memantau penggunaan/alokasi dari dana hibah tersebut.

\subsubsection{Skema Reducing Emissions from Deforestation and Forest Degradation (REDD)}

Konvensi Kerangka Kerja PBB tentang Perubahan Iklim atau United Nations Framework Convention on Climate Change (UNFCCC) merupakan hasil kesepakatan dari KTT Bumi. UNFCCC merupakan sebuah kesepakatan yang akhirnya diterima secara universal sebagai komitmen politik internasional tentang perubahan iklim. UNFCCC bertujuan untuk menstabilkan konsentrasi gas rumah kaca di atmosfer sehingga tidak menimbulkan gangguan terhadap kondisi iklim di dunia. Konvensi ini mulai berlaku sejak tanggal 21 Maret 1994 setelah diratifikasi oleh 50 negara. Hingga saat ini jumlah anggota UNFCCC adalah 192 negara. Indonesia meratifikasi UNFCCC melalui Undang-Undang No. 6 tahun 1994 (http://mailarchive.com/forum-

pembacakompas@yahoogroups.com/msg26744

diakses pada tanggal 05-05-2012).

Forum pengambilan keputusan tertinggi dalam kerangka UNFCCC adalah Conference of Parties (COP) yang diadakan setiap tahunnya. COP bertanggung jawab untuk mengkaji ulang implementasi konvensi dan instrumen legal lainnya terkait dengan konvensi. Selain itu COP berkewajiban membuat keputusan yang diperlukan untuk meningkatkan efektivitas implementasi konvensi. Salah satu hasil dari COP yang dipakai sebagai mekanisme penurunan emisi gas rumah kaca yaitu Protokol Kyoto (http://www.deptan.go.id/kln/pdf/unfccc.pdf diakses pada tanggal 01-05-2012).

Protokol Kyoto lahir dalam COP ke 3 tahun 1997. Tujuan pokok dari Protokol Kyoto yaitu mengatur peserta UNFCCC untuk memastikan bahwa emisi gas rumah kacanya tidak melebihi jumlah yang disepakati dengan tujuan mengurangi emisinya sedikitnya 5\% dibawah emisi tahun 1990 dalam jangka waktu 2008-2012 (http://www.wahanalingkunganhidup.html/4.htm diakses pada tanggal 01-05-2012).

Protokol Kyoto habis masa perjanjian pada 2012, namun implementasinya kurang dirasakan maksimal oleh banyak pihak. Oleh sebab itu dunia internasional mempersiapkan suatu kesepakatan pengganti yang diharapkan dapat meneruskan cita-cita dari kesepakatan Protokol Kyoto yang dinamakan Reducing Emission from Deforestation and Forest Degradation (REDD).

Reducing Emission from Deforestation and Forest Degradation (REDD) merupakan kesepakatan yang dirancang sebagai pengganti Protokol Kyoto. Skema REDD merupakan mekanisme pemberian insentif oleh negara industri maju yang memiliki kewajiban untuk menurunkan emisi gas rumah kacanya kepada negara-negara berkembang seperti Indonesia, Brazil, Papua Nugini, Gabon, Kolombia, Republik Kongo, Republik Demokratik Kongo, Kamerun, Kosta Rika, Meksiko dan Peru sebagai pemilik 50\% hutan tropis dunia.

Insentif ini dapat mendorong pengelolaan hutan yang lebih lestari dengan menyediakan aliran pendapatan berkelanjutan. Pengurangan emisi diperhitungkan sebagai kredit karbon. Insentif ini juga mendorong negara-negara berkembang agar berhasil mengurangi emisi karbonnya dengan menekan tingkat kegiatan deforestasi dan degradasi hutannya.

Papua Nugini dan Kosta Rika bersama dengan negara-negara yang tergabung dalam Koalisi Pemilik Hutan Tropis (Coalition for Rain Forest Nations atau CfRFN) pada COP ke 11 di Montreal, Kanada mengajukan proposal tentang insentif untuk menghindari deforestasi (avoided deforestation). Karena koalisi negara tersebut merasa sebagai negara pemilik hutan mereka tidak diuntungkan dengan mekanisme dibawah peraturan Protokol Kyoto. Maka 
dari itu, pada kesepakatan setelah berakhirnya Protokol Kyoto diharapkan akan lebih fleksibel terhadap semua negara baik negara yang termasuk dalam Annex 1 maupun negara-negara non-Annex 1. Pada COP ke 13 di Bali, Indonesia, REDD kemudian disepakati dengan menyepakati beberapa hal penting antara lain terkait aspek scientific, teknis dan metodologi serta pertukaran informasi.

Tujuan awal dari REDD adalah untuk mengurangi gas rumah kaca. REDD dilaksanakan dengan prinsip menghormati kedaulatan negara (sovereignty). Negara industri maju yang bersepakat dalam REDD, memberikan dukungan terhadap capacity building, transfer teknologi dibidang metodologi dan institutional, pilot/demonstration activities.

REDD merupakan dua hal yang diintegrasikan, pertama REDD sebagai tujuan dan kedua REDD sebagai mekanisme pembiayaan. Sebagai tujuan, REDD diharapkan sebagai skema pengurangan emisi Gas Rumah Kaca dengan cara pengurangan laju deforestasi dan degradasi hutan. Sedangkan sebagai mekanisme pembiayaan, REDD membentuk tata cara pembiayaan atau kompensasi bagi usaha pengurangan deforestasi dan degradasi hutan yang diharapkan akan berdampak pada turunnya emisi Gas Rumah Kaca terutama $\mathrm{CO}_{2}$.

REDD-Plus (REDD+) merupakan perluasan dari REDD, yang menambahkan areal peningkatan cadangan karbon hutan ke dalam cakupan awal strategi REDD berupa peranan konservasi, pengelolaan hutan secara lestari dan peningkatan cadangan karbon.

\subsection{Metode Penelitian}

\subsubsection{Desain Penelitian}

Desain penelitian yang peneliti pakai menggunakan pendekatan penelitian kualitatif yang dikutip dari buku "Pedoman Penulisan Skrispi Dan Pelaksanaan Sidang FISIP Universitas Komputer Indonesia". Desain penelitian kualitatif pada umumnya menggunakan metode penelitian deskriptif analitis.

Metode deskriptif adalah dimana data dapat berupa gejala yang dikategorikan bentuk lain seperti foto, dokumen, yang menunjukkan kepada prosedurprosedur penelitian yang menghasilkan data kualitatif; ungkapan atau catatan orang itu sendiri atau tingkah laku mereka yang terobservasi. Pendekatan ini mengarah kepada keadaan-keadaan dan individuindividu secara holistik (utuh) (Tim Penyusun, 2011: 21).
Menurut W. Lawrence Neuman dalam buku berjudul "Social Research Methods, Qualitive and Quantitive Approaches", deskriptif menggambarkan secara spesifik suatu situasi, social setting, ataupun suatu hubungan. Melalui pendekatan ini diharapkan dapat memberikan gambaran mengenai kerjasama yang dilakukan antara Indonesia - Norwegia melalui skema Reducing Emissions from Deforestation and Forest Degradation (REDD+) dalam upaya penyelamatan hutan Indonesia. Penulisan ini juga bersifat analitis karena menjelaskan keterkaitan antara variabel independen dan variabel dependen.

\subsubsection{Teknik Pengumpulan Data \\ 3.2.2.1 Studi Pustaka}

Teknik pengumpulan data yang dilakukan dalam penelitian ini akan dilakukan melalui studi kepustakaan (library research). Teknik ini mengasumsikan bahwa setiap kumpulan informasi tertulis dapat digunakan sebagai indikator sikap, nilai, dan maksud politik dengan cara menelaah secara sistematis menurut kriteria penafsiran kata dan pesan tertentu. Dengan demikian data-data yang digunakan adalah data-data sekunder yang berasal dari dokumentasi dan publikasi. Bentuk data-data tersebut dapat ditemui pada buku referensi, jurnal, majalah atau laporan dari instansi terkait, di samping pemanfaatan sumber-sumber tulisan lainnya seperti fasilitas dan jasa internet untuk mendapatkan data tertulis yang telah didokumentasikan.

Teknik pengupulan data dalam penelitian ini bertujuan untuk memberikan analisa mengenai kerjasama Indonesia - Norwegia, yang diawali dengan pengumpulan data, Letter of Intent (LoI) sebagai naskah perjanjian dan dokumen terkait lainnya.

Data yang diperoleh dari dokumen tertulis kemudian ditelaah, dikelompokan dan dianalisis untuk memperkaya pemanahaman tentang REDD+ yang menjadi salah satu instrument penyelesaian permasalahan dalam mengurangi emisi gas rumah kaca dan faktor yang melatarbelakangi terbentuknya kerjasama antara pemerintah Indonesia dan pemerintah Norwegia dalam kerangka REDD+ dalam rangka penyelamatan hutan Indonesia, selain itu untuk mengetahui program apa saja yang telah dilakukan oleh kedua negara dalam rangka penyelamatan hutan Indonesia. Mengetahui, memahami, dan meneliti kendala-kendala dalam skema REDD+ dalam upaya penyelamatan hutan Indonesia serta meneliti sejauh mana peranan REDD+ dan prospek dari kerjasama 
yang tengah dijalankan oleh pemerintah Indonesia dan pemerintah Norwegia dalam upaya menyelamatkan hutan Indonesia.

Dalam penelitian ini tidak menggunakan teknik wawancara dikarenakan terdapatnya keterbatasan peneliti dalam mencari dan mendapatkan izin untuk mewawancarai sumber yang berkompeten dalam bidang dalam penelitian ini.

\subsubsection{Teknik Analisa Data}

Teknik analisa yang dipergunakan peneliti adalah data display (penyajian data), dimana susunan informasi yang memungkinkan dapat ditariknya suatu kesimpulan, sehingga memudahkan untuk memahami apa yang terjadi (Tim Penyusun, 2011: 23). Neuman menjelaskan dalam penelitian kualitatif menginterpretasikan data dengan cara mengartikan, menerjemahkan dan membuat data tersebut menjadi lebih mudah untuk dipahami melalui sudut pandang peneliti. Tingkat analisis induksionis dalam penelitian ini dimana unit eksplanasinya, yakni kerjasama

\section{Hasil dan Pembahasan}

4.1 Latar Belakang Pemerintah Norwegia Menerima Proposal REDD+ dari pemerintah Indonesia

Pada tanggal 9 Juli 1993 Norwegia meratifikasi Konvensi Kerangka Perubahan Iklim (UNFCCC) serta Protokol Kyoto pada 30 Mei 2002. Di bawah Protokol Kyoto, Norwegia termasuk ke dalam negara Annex 1 yang memiliki kewajiban untuk menurunkan emisi hingga 5.2\% di bawah tingkat emisi tahun 1990. Total emisi Gas Rumah Kaca Norwegia adalah sekitar 54,8 juta ton $\mathrm{CO}_{2}$ pada tahun 2003. Emisi ini naik sekitar 9\% pada periode 1990-2003. Faktor utama di balik pertumbuhan $\mathrm{CO}_{2}$ ini didapat dari sektor perminyakan, industrialisasi, penggunaan energi fosil dan transportasi.

Norwegia berkomitmen untuk menjaga emisi Gas Rumah Kaca nya tidak melebihi tingkat emisi pada tahun 1990 lebih dari 1\% pada periode 2008-2012. Namun Norwegia dan sebagian besar negara-negara lain yang termasuk ke dalam negara Annex 1 merasa kesulitan untuk melakukan hal tersebut dikarenakan dalam upaya menurunkan emisi Gas Rumah Kaca hingga $5.2 \%$ itu berarti negara-negara tersebut diharuskan untuk mengurangi emisi 6 jenis Gas Rumah Kaca, salah satunya $\mathrm{CO}_{2}$ yang berarti mereka harus mengurangi aktivitas industrial di dalam negara mereka masing-masing.
Indonesia - Norwegia lebih tinggi tingkatannya dari unit analisanya, yaitu upaya penyelamatan hutan Indonesia melalui skema REDD+.

Berangkat dari penjelasan diatas, maka penelitian ini untuk mengetahui apa yang melatarbelakangi diterimanya proposal REDD yang ditawarkan oleh pemerintah Indonesia kepada pemerintah Norwegia, setelah diterima apa saja program yang dilakukan oleh kedua negara dalam upaya penyelamatan hutan Indonesia, selanjutnya melalui teknik ini kemudian ditelaah apa saja yang menjadi kendala-kendala yang menyebabkan program dari kerjasama ini menjadi terhambat serta sejauh mana peran REDD+ dalam upaya penyelamatan hutan Indonesia juga prospek kerjasama yang dilakukan Indonesia - Norwegia kedepannya. Untuk mengetahui hal itu, maka dilakukan studi pustaka berupa informasi yang didapat dari buku, jurnal, publikasi, koran maupun penelusuran internet.

Untuk membantu negara Annex 1 yang terikat kewajiban penurunan emisi, Protokol Kyoto menetapkan berbagai mekanisme fleksibel (flexible mechanisms) seperti perdagangan emisi (emission trading), mekanisme pembangunan bersih (clean development mechanisms), dan implementasi bersama (joint implementation). Mekanisme tersebut memungkinkan negara industri untuk memperoleh kredit emisi dengan cara membiayai proyek pengurangan emisi di negara di luar negara Annex 1. Protokol Kyoto memiliki masa komitmen yang berakhir pada tahun 2012 .

Namun, hingga masa berakhirnya Protokol Kyoto, nampaknya tidak ada komitmen yang ditunjukkan lewat konvensi legal oleh negara-negara maju untuk menekan tingkat emisi, terungkap dalam fakta bahwa emisi karbon malah meningkat 2,6\% di tahun 2012 atau sekitar 58\% jauh lebih tinggi dibandingkan emisi karbon dunia tahun 1990 (http://politik.pelitaonline.com/news/2012/12/11/negar a-nodai-kom itmen-protokolkyoto\#.UgyvtkwdYY di akses pada tanggal 28/07/2013). Dengan tidak berhasilnya pelaksanaan Protokol Kyoto kemudian dilanjutkan dengan skema penurunan emisi baru yang dikenal dengan nama Reducing Emission from Deforestation and Forest Degradation (REDD) yang 
diharapkan dapat menjadi mekanisme penurunan emisi yang lebih baik dibandingkan Protokol Kyoto.

Norwegia merupakan negara dengan luas wilayah negara yang cukup besar yakni sekitar $385.199 \mathrm{~km}^{2}$, namun Norwegia tidak memiliki cukup hutan yang dapat digunakan sebagai penyerap karbon. Bentang alam Norwegia pada umumnya kasar dan bergunung-gunung, yang sebagian besar tertutup oleh gletser. Padahal negara yang terletak di Semenanjung Skandinavia ini merupakan salah satu negara dengan tingkat kegiatan industrialisasi terbesar di dunia. Maka dari itu, Norwegia memerlukan kerjasama dengan negara-negara pemilik hutan untuk membayar hutang karbon warisan dari rezim Protokol Kyoto.

Norwegia bersedia memberikan hibah kepada negara berkembang melalui skema REDD+ khususnya negara pemilik hutan yang berkomitmen untuk menurunkan emisi Gas Rumah Kaca, dimana salah satunya adalah Indonesia. Pada bulan Oktober 2009, Presiden Susilo Bambang Yudhoyono menyatakan komitmen untuk mengurangi emisi $\mathrm{CO}_{2}$ Indonesia sebanyak $26 \%$ hingga $41 \%$ di tahun 2020 dengan dukungan dana dari negara maju. Dengan komitmen seperti itu Indonesia telah menetapkan target absolut dan Norwegia ingin membantu upaya pemerintah Indonesia mencapai komitmen tersebut. Pemberian hibah ini sejalan dengan kesepakatan Conference of Parties (COP) yang diadakan setiap tahun, yakni gagasan bagi negara-negara industri untuk mengganti kewajiban penurunan karbon di dalam negerinya sendiri dengan memberikan hibah kepada negaranegara berkembang yang memiliki sumber daya hutan untuk mengurangi laju deforestasi dan kerusakan hutan.

Norwegia dan Indonesia telah sepakat bekerja sama untuk mendukung upaya Indonesia mengurangi emisi gas rumah kaca dari penebangan dan degradasi hutan serta tanah gambut. Norwegia mendukung upaya ini melalui bantuan dana sampai dengan 1 milyar USD berdasarkan kinerja Indonesia, dalam waktu 7-8 tahun sejak ditandatanganinya nota kesepahaman (MoU) pada 2010 .

Terdapat dua alasan yang menjadi latar belakang diterimanya proposal REDD dari pemerintah Indonesia oleh pemerintah Norwegia. Pertama, Indonesia sebagai pemilik hutan terbesar ketiga didunia dengan didalamnya terdapat berbagai aneka kekayaan hayati beperan sebagai paru paru dunia yang berperan sebagai penyedia strategis kebutuhan udara bersih dunia. Kedua, skema dan mekanisme pembiayaan dalam REDD yang diajukan Indonesia dinilai sesuai oleh pemerintah Norwegia yang memiliki kewajiban untuk membayar hutang karbon sebagai kompensasi dari kegiatan industrinya. Berdasarkan alasan tersebut maka Norwegia menyetujui untuk menerima proposal REDD dari Indonesia.

4.2 Program Yang Dilakukan Pemerintah Indonesia dan Norwegia Melalui Kerangka REDD+ Dalam Upaya Penyelamatan Hutan Indonesia

Upaya yang dilakukan antara pemerintah Indonesia dan Norwegia dalam rangka penyelamatan hutan Indonesia tertuang dalam tiga fase yang terdapat dalam Letter of Intent (LoI) yang ditandatangani kedua negara pada 26 Mei 2010 di Norwegia. Pada fase pertama, dana akan digunakan untuk memfinalisasikan strategi iklim dan hutan Indonesia dan menerapkan kebijakan serta reformasi institusional. Pada fase kedua, tujuan yang ingin dicapai adalah memastikan Indonesia siap berkontribusi mengurangi emisi dan pada saat yang bersamaan memulai mitigasi dalam skala yang lebih luas. Di fase ketiga, mekanisme kontribusi pengurangan gas emisi yang telah diverifikasi akan dijalankan dalam skala nasional.

Tabel 1. Fase Dalam Letter of Intent (LoI)

\begin{tabular}{|c|c|}
\hline Fase & Program \\
\hline $\begin{array}{l}\text { Fase I : } \\
\text { Persiapan }\end{array}$ & $\begin{array}{llr}\text { 1. } & \text { Pembentukan Rencana } & \text { Aksi } \\
& \text { Nasional (Strategi Nasional } \\
& \text { REDD di Indonesia) } \\
\text { 2. } & \text { Pembentukan Satuan } \\
& \text { Tugas } \\
& \text { mengkoordinasikan usaha-usaha } \\
& \text { pengembangan dan implementasi } \\
& \text { REDD } \\
\text { 3. } & \text { Merancang dan menetapkan } \\
& \text { instrumen pengelolaan dana hibah } \\
\text { 4. } & \text { Menetapkan } \\
& \text { Percontohan }\end{array}$ \\
\hline $\begin{array}{l}\text { Fase II : } \\
\text { Transformasi }\end{array}$ & $\begin{array}{l}\text { 1. Mekanisme MRV (Measurement, } \\
\text { Reporting and Verification) } \\
\text { 2. Penerbitan Moratorium } \\
\text { 3. Membangun Database Hutan } \\
\text { Rusak Untuk Pembangunan } \\
\text { Ekonomi dan Investasi } \\
\text { 4. Penegakkan Hukum } \\
\text { Pemberantasan Illegal Logging } \\
\text { 5. Penyelesaian Konflik Lahan }\end{array}$ \\
\hline
\end{tabular}




\begin{tabular}{|l|l|}
\hline Fase III : & Implementasi dari mekanisme \\
\hline Pengurangan & pengurangan emisi berdasarkan \\
emisi & kontribusi yang diverifikasi \\
berdasarkan & \\
kontribusi & \\
yang & \\
diverifikasi & \\
\hline
\end{tabular}

\subsection{Kendala Yang Dialami Program REDD+ Dalam Upaya Penyelamatan Hutan Indonesia}

Salah satu tantangan yang dihadapi REDD berasal dari dalam mekanisme REDD itu sendiri. Tantangan-tantangan besar di dalam mekanisme ini termasuk bagaimana mengukur karbon secara akurat, bagaimana memastikan dana sampai ke komunitas hutan dengan transparan dan efisien, siapa yang akan bertanggung jawab apabila hutan ternyata tetap rusak, serta sumber pendanaan. Lebih dari 30 model tentang bagaimana REDD+ seharusnya dilaksanakan telah diajukan oleh berbagai negara dan organisasi non pemerintah.

Tantangan lain berasal dari masyarakat adat Indonesia. Meskipun terlihat mudah, namun implementasi skema REDD dilapangan cukup rumit karena melibatkan berbagai kelompok dengan kepentingan yang berbeda-beda. REDD diterapkan dengan menjunjung tinggi perlindungan Hak Asasi Manusia (HAM), menurunkan angka kemiskinan, dan melindungi hak-hak masyarakat adat termasuk perlindungan keanekaragaman hayati.

Di Indonesia, sebagian besar rakyatnya hingga kini masih hidup dalam lingkungan ikatan masyarakat adat yang sangat kuat. Oleh karena itu, implementasi REDD di Indonesia menghadapi tantangan yang unik. Sebagian orang Indonesia bertempat tinggal di sekitar dan/atau dalam hutan. Bagi mereka, hutan merupakan sumber hidup dan kehidupan yang tidak terpisahkan dari kegiatan sehari-hari. Hutan digunakan untuk area berladang/berkebun, tempat berburu dan menangkap hewan, mengumpulkan hasil hutan, sumber obatobatan dan juga tempat untuk melakukan ritual adat. Pola kepemilikan lahan masyarakat mengacu pada kepemilikan secara komunal, sedangkan penggunaannya dilakukan berdasarkan musyawarah.

Tantangan lainnya adalah permasalahan mengenai perlindungan hutan Indonesia. Terdapat lima masalah utama soal perlindungan hutan di Indonesia yang dapat menghambat kemajuan skema REDD, yaitu:
1. Penebangan hutan dalam skala besar yang masih terus terjadi di Indonesia.

Salah satu penyebab penebangan hutan yang terus terjadi adalah karena lahan hutan yang berubah fungsi, salah satunya untuk memenuhi kebutuhan perkebunan.

2. Ekonomi Indonesia yang masih sangat tergantung pada sumber alam.

Kekayaan alam masih menjadi pilar penyokong utama pemasukan di Indonesia. Sekitar $70 \%$ pendapatan non pajak Indonesia berasal dari kekayaan alam.

3. Perluasan wilayah pertanian, perkebunan, serta tambang.

Semakin banyaknya investor asing di bidang kelapa sawit dan tambang batubara menyebabkan ekspansi besar-besaran perkebunan kelapa sawit dan aktivitas pertambangan. Beban hutan pun bertambah karena lahan perkebunan kelapa sawit biasanya berasal dari kawasan hutan yang kemudian berubah fungsi. Selain itu, deposit batubara kebanyakan terletak di kawasan hutan. Industri kelapa sawit dan tambang yang bisa mengancam kelestarian hutan mendapat kemudahan dan dukungan dari sektor finansial. Karena industri ini sangat menguntungkan, maka perbankan memberi bunga rendah untuk pembukaan dan perluasan usaha kelapa sawit atau pertambangan. Belum lagi pajak bumi dan bangunan untuk hutan yang sangat rendah, sehingga memudahkan individu atau perusahaan untuk „memiliki“ ribuan hektar hutan dengan pajak murah.

4. Tabrakan administrasi.

Sekitar 70\% dari lahan di Indonesia adalah hutan, dan dikuasai oleh negara. Dengan desentralisasi, hak pengelolaan hutan pun dikembalikan ke pemerintah lokal. Sayangnya, situasi ini malah memunculkan tubrukan antara ijin penggunaan lahan yang dikeluarkan oleh pemerintah pusat dan pemerintah daerah. Tumpang tindih ijin pengelolaan hutan pun bisa menambah beban pada upaya pelestarian.

5. Keputusan-keputusan politik.

Proses pengambilan keputusan menjadi kelemahan terbesar. Salah satu yang menjadi sorotan adalah tidak 
transparannya proses pemberian ijin pengelolaan untuk industri-industri yang bersifat mengeruk kekayaan alam. Selain

\section{Kesimpulan dan Rekomendasi}

\subsection{Kesimpulan}

Berdasarkan penelitian yang telah dilakukan serta apa yang telah dipaparkan pada bab sebelumnya. Maka peneliti dapat mengambil kesimpulan dari Kerjasama Indonesia - Norwegia Melalui Skema Reducing Emissions from Deforestation and Forest Degradation (REDD) Dalam Upaya Penyelamatan Hutan Indonesia.

1. Sejak isu Lingkungan Hidup mulai menjadi perhatian di tahun 1980-an terutama setelah diratifikasinya UNFCCC yang kemudian melahirkan Protokol Kyoto dan REDD sebagai mekanisme penting dalam rangka pencegahan pemanasan global dan penurunan emisi Gas Rumah Kaca, negara-negara pemilik hutan yang kebanyakan merupakan negara berkembang seperti mendapat angin segar dalam kancah perpolitikan internasional. Negara-negara tersebut yang semula kurang di"perhatikan" sekarang memiliki daya tawar politik yang lebih kuat.

2. Norwegia sebagai negara Annex 1 dalam Protokol Kyoto memiliki kewajiban yang mengikat untuk menurunkan emisi Gas Rumah Kaca nya, namun Norwegia memiliki keterbatasan dalam melakukan hal tersebut dari dalam negerinya, maka dari itu Norwegia membutuhkan negara lain untuk melakukan kerjasama untuk membayar hutang karbonnya tersebut.

3. Norwegia menerima proposal Indonesia melalui kerangka REDD yang dianggap paling sesuai bagi Norwegia. Kerjasama ini disepakati dalam bentuk Letter of Intent yang ditandatangani pada tanggal $26 \mathrm{Mei}$ 2010 yang terdiri dari tiga fase dengan waktu pelaksanaan 7-8 tahun setelah ratifikasi.

4. Hingga kini kerjasama tersebut telah memasuki fase kedua. Sampai sejauh ini, kerjasama yang dilakukan Indonesia Norwegia terbilang cukup sukses, skema itu, proses pengambilan keputusan juga jarang melibatkan partisipasi masyarakat lokal.

REDD cukup berperan dalam upaya penyelamatan hutan Indonesia terbukti dari hasil moratorium pertama yang telah menyumbang $16,57 \%$ atau setara dengan terlestarikannya hutan Indonesia hingga 489.000 juta ton $\mathrm{CO}_{2}$ untuk penyerapan Gas Rumah Kaca, meskipun implementasi dari semua program yang terdapat dalam fase-fase LoI belum semua terlaksana dikarenakan terdapatnya masalah-masalah yang belum terselesaikan.

5. Diantara kendala tersebut berasal dari kendala teknis, kendala kultural yang berasal dari masyarakat adat Indonesia dan kendala kebijakan dalam perlindungan hutan Indonesia.

\subsection{Saran}

\subsubsection{Saran Untuk Kelembagaan REDD dan Pemerintah Indonesia}

Pertama, transparansi dalam pengelolaan dana hibah. Kedua, sebelum dilaksanakannya program ini, seharusnya pemerintah melalui badan yang ditunjuknya melakukan pengenalan skema REDD kepada masyarakat khususnya yang tinggal disekitar hutan sehingga mereka dapat turut berpartisipasi dalam upaya menjaga kelestarian hutan. Ketiga, pemerintah dan kelembagaan REDD juga harus dapat mengatasi dan menyelesaikan permasalahan dengan masyarakat adat sehingga mampu bahu membahu bekerjasama untuk mengatasi permasalahan kehutanan Indonesia. Keempat, pemerintah harusnya lebih tegas dalam memberikan sanksi kepada para oknum pengusaha hutan.

\subsubsection{Saran Untuk Penelitian Selanjutnya}

Hasil penelitian ini diharapkan akan menambah khazanah keilmuwan, memperluas pemahaman, menambah wawasan, dan memberikan masukan bagi pengelolaan kehutanan. Hasil Pengetahuan ini juga dapat dijadikan referensi umumnya bagi mahasiswa yang melakukan penelitian berkaitan dengan penelitian ini khususnya bagi mahasiswa program studi Ilmu 
Hubungan Internasional dan dapat digunakan sebagai pedoman pustaka lebih lanjut.

Peneliti secara sadar sangat meyadari kekurangan penelitian yang telah disusun, dari awal penulisan skripsi hingga peneliti mendapatkan hasil dari apa yang telah diteliti. Peneliti menyarankan apabila dilakukan penelitian lanjutan sebaiknya

\section{Acuan Buku}

Baylis, John dan Steve Smith. 2011. The Globalization of World Politics: An Introduction To International Relations fifth edition. UK: Oxford University Press

Ikbar, Yanuar. 2007. Ekonomi Politik Internasional 2: Implementasi Konsep dan Teori. Bandung : PT. Rafika Aditama

Kusumaadmaja, Mochtar. 2003. Pengantar Hubungan Internasional. Bandung: PT. Alumni

McClelland, Charles. 1986. Ilmu Hubungan Internasional: Teori Dan Sistem. Jakarta: C.V. Rajawali

Murdiyaso, Daniel. 2007. Protokol Kyoto: Implikasinya Bagi Negara Berkembang. Jakarta: Kompas

Perwita, A.A. Banyu dan Yanyan Mochamad Yani. 2005. Pengantar Ilmu Hubungan Internasional. Bandung: PT Remaja Rosdakarya

Rudy, T. May. 1993. Pengantar Ilmu Politik: Wawasan Pemikiran Dan Kegunaannya. Bandung: PT. Refika Aditama 2002. Hukum Internasional 1. Bandung:

PT. Refika Aditama.

2003. Hubungan Internasional Kontemporer Dan Masalah - Masalah Global. Bandung: PT. Refika Aditama 2009. Pengantar Ilmu Politik. Bandung: PT.

Refika Aditama

Parthiana, I Wayan. 2003. Pengantar Hukum Internasional. Bandung: Mandar Maju

Soeprapto. 1997. Hubungan Internasional: Sistem, Interaksi Dan Perilaku. Jakarta: Raja Grafindo Persada

\section{Acuan Website}

\section{RUJUKAN ELEKTRONIK}

REDD, Apakah Itu?. Melalui http://www.reddindonesia.org/index.php?option= com_content $\&$ view $=$ article $\&$ id $=180 \&$ Ite $\operatorname{mid}=6[13 / 03 / 2012]$. diberikan tambahan informasi atau data yang lebih banyak, penelitian sebaiknya melengkapinya dengan metode wawancara yang lebih dalam, menggunakan jumlah sampel penelitian yang lebih banyak dan lokasi pekerjaan yang lebih luas sehingga responden yang didapat pun dapat lebih bervariasi.

Pemanasan Global. Melalui http://id.wikipedia.org/ wiki/Pemanasan_Global[13/03/2012].

Perubahan Iklim. Melalui http://www.reddindonesia.org/index.php?option=com content $\&$ view $=$ article $\&$ id=223\&Itemid= 83 [13/04/2012].

Indonesia Forest Information and Data. Melalui http://rainforests.mongabay.com/deforest ation/2000/Indonesia.htm [13/04/2012].

UN-REDD. UN-REDD di Indonesia. Melalui http://storage.jakstik.ac.id/Produk Hukum/kehutanan/6.UNREDD_Factshee t_0.pdf [13/04/2012].

http://www.psil.undip.ac.id/index.php?option=com_co ntent $\&$ view $=$ article $\&$ id $=122 \&$ Itemid $=27$ [14/04/2012].

Degradasi Hutan 10 Tahun Terakhir Mencapai Dua Juta Hektar. Melalui http:// www.antaranews.com/print/31978/degra dasi-hutan-10-tahun-terakhir-mencapaidua-juta-hektar [21/06/2013].

Manfaat Hutan. Melalui http://pengertiandefinisi.blogspot.com/2010/10/manfaathutan.html [19/07/2013].

Artharini, Isyana. Lima Masalah Perlindungan Hutan. Melalui http://id. berita.yahoo.com/limamasalah-utama-perlindungan-hutanindonesia. html [28/07/2013]. 